\title{
UPRAVLJANJE RIZIKOM U POSLOVANJU POSLOVNIH PROIZVODNIH SISTEMA
}

\section{THE RISK MANAGEMENT OPERATIONS OF THE BUSINESS OF MANUFACTURING SYSTEMS}

\section{Jelena Avakumović}

Univerzitet Union, Fakultet za poslovno industrijski menadžment, Kneza Višeslava 27, 11000 Beograd, Republika Srbija

\section{Čedomir Avakumović}

Univerzitet Union, Fakultet za poslovno industrijski menadžment, Kneza Višeslava 27, 11000 Beograd, Republika Srbija

\section{Julija Avakumović}

Visoka tekstilna strukovna škola za dizajn, tehnologiju i menadžment, Starine Novaka 24, 11000 Beograd, Republika Srbija

\section{(๑) MESTE NGO}

\section{Sažetak:}

U radu je ukratko ukazano na analizu i klasifikaciju rizika koje se mogu pojaviti u poslovanju PPS-a. Da bi se moglo uspešno upravljati rizicima, potrebno je upoznati,odnosno predvideti ih i znati njihov mogući uticaj na profit. $U$ poslovanju PPS-a je većina poslovnih poteza riskantna i nepredvidiva, pa je zato $i$ bitno te nepredvidljive varijable u poslovanju PPS-a pokušati alternativno planirati i eventualno ukoliko u poslovanju se pojave imati spreman odgovor.

\section{Ključne reči:}

biznis, rizik, upravljanje, promene, preduzetnik, menadžer rizika, proizvodni poslovni sistemi

\section{Abstract:}

This paper briefly points out the analysis and classification of risk that may appear in business operations in production systems (BPS). In order to successfully manage the risks, there is a need to know or predict them and be aware of their potential impact on profit. In BPS business most business moves are risky and

Adresa autora zaduženog za korespodenciju: unpredictable. That is why it is very important to predict Jelena Avakumović all possible variables and have a solution in case they 䤵" jelenalav@yahoo.com appear in business.

Keywwords:

business, risk, management, change, entrepreneur, manager of risk, business production system 


\section{Uvod}

Projekat poslovanja se analizira i priprema u sadašnjosti a odluke o njihovoj realizaciji se mogu donositi takođe $\mathrm{u}$ isto vreme, ali konkretna realizacija poslovanja poslovnih proizvodnih sistema (u daljem tekstu PPS-a) se obavlja u budućnosti. Po realizaciji određenog poslovnog poduhvata mogu se očekivati i planirati rezultati. Ta budućnost je neizvesna i nepoznata, pa i očekivani rezultati poslovanja su neizvesni, odnosno rizični.

Upravljanje rizikom u PPS-u je jedan sveobuhvatni pristup identifikaciji rizika i upravljanja rizikom u svim aspektima poslovanja - i to sa strateške tačke gledišta. Sa obzirom na to da se svaki rizik menja što se tiče njegovog uticaja i urgentnosti, PPS bi moralo da odgovarajuće reaguje da bi se osiguralo da se svaka šteta ograniči i da se ispitaju sve mogućnosti za nastanak rizika kroz praćenje „rupa“ na tržištu koje nosi nove rizike. Zapravo glavna karakteristika uspešnog PPS-a je njegova mogućnost da predvidi globalne rizike i da se sa njima nosi bolje od drugih sličnih organizacija. Pri ovom scenariju gde su ulozi veoma visoki, uloga koju ima „menadžer rizika“ postaje još važnija. Fokus na objektivnost i profesionalizam kreirao je novi imidž menadžera, koji je danas prihvaćen kao osoba koja se bavi veoma važnom delatnošću koja zaista ima veliki uticaj i dovodi do promena.

Kad se PPS ne bi suočavali sa rizikom, ne bi bilo potrebe da se zapošljava osoblje, koje se bavi menadžment rizikom. PPS bi uvek imao potpunu kontrolu i ne bi imalo potrebe da se vrši pregled, prilagođavanja, podešavanja kao ni implementacija interne kontrole. Menadžer rizika postoji zato što se planovi ne odvijaju onako kako je to zamišljeno i stvari nisu uvek onakve kakvim se čine.

Menadžer rizika je potreban zato što je potrebno obezbediti da PPS razume sve rizike i da je preuzeo sve korake da rešava predvidive probleme kao i da iskoristi potencijalne prednosti.

Većina preduzetnika nisu nerazumni optimisti, jer oni znaju da u poslovnom svetu nije ništa tako sigurno da ne može da „propadne“. Jedan pesnik je ispevao: „Jedino u životu što je sigurno i stalno, to su promene“. Znači, sve ostalo je prolazno i promenljivo..

Rizik uključuje neizvesnost i verovatnoću da će se dogoditi nešto nepredviđeno i obično nešto što ne želimo i što nismo planirali. Svaki poslovni poduhvat je riskantan. U poslovanja PPS-a ima puno pitanja koja brinu većinu vlasnika PPS-a. Među njima malo onih koju su apsolutno predvidiljivi i koji se mogu planirati i kontrolisati do izvesne mere, kao što su (Avakumović \& Bojović, 2010)

- očekivani obim proizvodnje/prometa,

- troškovi zarada režijski troškovi,

- nabavna cena repromaterijala i opreme,

- prodajna cena proizvoda i usluga,

- porezi, takse i drugo.

Ostale varijable poslovanja PPS-a su nepredvidljive i veoma se teško mogu kontolisati. Ti nepredviđeni rizici su događanja na tržištu, odnosno u bližem i daljem ekonomskom okruženju, na koja vlasnici malog biznisa ne mogu imati nikakav uticaj, a možda i uvid. To su rizici koji mogu nastati, zbog:

- promene u ukusima i trendovima na tržištu i njihov uticaj na poslovanja PPS-a,

- aktivnosti koje preduzimaju konkurenti,

- promene u monetarnoj sferi (inflacija, deflacija, devalvacija, revalvacija i dr.),

- promene u kreditnoj politici ( ekspanzija ili restrikcija kredita za nabavku repromaterijala i opreme i kupovinu na kredit robe),

- promene u lokalnoj samoupravi (zatvaranje neke fabrike, čiji su radnici kupci robe koje proizvodi PPS-a).

Poslovanja PPS-a je postaolo veoma složeno i odgovorno i njegovom realizacijom ima mnogo rizika, koje brojni biznismeni uspevaju da savladaju ili njihov negativan uticaj smanje na što manju meru štete.

Napor i borba da se rizici smanje i eleminišu, da se pobedi i ostvare postavljeni ciljevi su ideje vodilje poslovanja PPS-a .

\section{Analiza i klasifikacija rizika}

U razvoju poslovno - proizvodnih sistema poznati su primeri da su ti sistemi propali, jer njihovi vlasnici nisu blagovremeno procenili kada da napuste ili redefinišu određeni posao. Da se ovo ne bi događalo, potrebno je pre svakog značajnijeg poslovnog poteza, prethodno utvrditi stepen rizičnosti poduhvata koji planiramo da ostvarimo. Postavlja se pitanje kao znati da li neki posao treba povećati, zadržati na istom novou, smanjiti ili ugasiti. Potrebno je analizirati bitne pokazatelje događanja na tržištu i pokazatelje poslovanja i na taj način ćemo imati blagovremena saznanja i na osnovu tih 
podataka možemo doneti dobre odluke. Te analize mogu biti (Jokić, 2007):

- analiza opšteg kupoprodajnog trenda,

- analiza kretanja ponude,

- analiza ponašanja konkurenata i dr.

$\mathrm{Na}$ osnovu tih analiza moguće je upravljati rizikom. Da bismo mogli sigurnije poslovati u poslovanja PPS-a potrebno je upoznati blagovremeno rizike tog poslovanja. Samo poslovanje na tržištu, a naručito poslovanje sa dobavljačima i kupcima, izlaže vlasnike PPS-a velikom broju rizika. Ovi rizici se mogu javiti u različitim periodima poslovanja i na razne načine. Svi poslovi, pojave i aktivnosti, aktiviraju poneki rizik, ukazuju na veću ili manju opasnost da se dogodi nešto što može umaniti ili upropastiti i najbolje koncipirane planove vlasnika PPS-a, i tako in dovesti u različite teškoće. Rizike ne nosi samo poslovanje PPS-a već i sam život i svi oni se apsolutno ne mogu izbeći. Pravilnim odnosom prema njima, neke neizbežne rizike možemo minimizirati i tako ih svesti u razumne okvire koji će nam obezbediti i uspešnije poslovanje.

Da bi smo mogli smanjiti rizike moramo poznavati osnove i izvore nekih rizika koji se mogu pojaviti u poslovanju PPS-a:

- predvidivi i nepredvidivi rizici,

- eksterni i interni rizici,

- rizici prema fazi nastanka,

- rizik kod uvođenja novog projekta/proizvoda.

Prema stepenu predvidivosti (uočljivosti) rizici poslovanja PPS-a mogu se podeliti na:

- predvidive rizike,

- delimično predvidive rizike $\mathrm{i}$

- nepredvidive rizike.

Rizici koji mogu ugrožavati poslovanje PPS-a mogu dolaziti spolja iz okruženja, ali mogu nastati i unutar poslovnog sistema.

Rizici eksternog karaktera dolaze spolja, iz tržišnog ambijenta u kome se odvija poslovanje PPS-a. Oni mogu biti:

- rizici od nastupa i načina rada konkurencije,

- rizici od nedostupnosti ili ne zainteresovanosti kupaca,

- rizik od neplanirane pojave novih tehnologija,

- rizik u poslovanju sa bankom, dobavljačima, distributerima, špediterima i drugim komintentima,
- rizici uzrokovani ponašanjem državnih organa,

- rizici proizašli zbog institucionalne regulative,

- rizici od nepovoljnih promena u ambijentu (cenovnih odnosa, valutnog kursa, stope inflacije i dr.),

- rizici od pojave novih trendova u potrošnji.

Rizici internog karaktera se javljaju u poslovnom sistemu PPS-a. Oni mogu biti (Milosavljević, 2006):

- rizik od zastarevanja poslovnih i razvojnih faktora,

- rizik od nedostataka ideja i inovacija,

- rizik od neracionalnog i šablonskog rada,

- rizik od neodgovornog ponašanja osoblja,

- rizik od nezakonitog i nemoralnog ponašanja,

- rizik od krađa, provala, pronevera i dr.

- rizik od požara, poplava i drugih elementarnih nepogoda,

- rizik od ekoloških akcedenata,

- rizici od kala, rastura, loma, kvarenja, demodiranja, gubljenje upotrebljivosti i dr.

Rizici prema fazi i mestu nastanka, mogu se razvrstati u dve grupe:

- rizici u izboru poslovne koncepcije i

- rizici u promeni poslovne koncepcije.

Rizici u izboru pogrešne poslovne, odnosno marketinške koncepcije, u poslovanju PPS-a su izvesni i nose mnoge opasnosti. To su:

- rizik od pogrešnog segmentiranja tržišta,

- rizik od izbora pogrešnog ciljnog segmenta,

- rizik od pogrešnog tržišnog pozicioniranja,

- rizik od nepostojanja ili gubitka prepoznatljivosti identiteta firme,

- rizik od primene pogrešne marketing strategije,

- rizik od izbora loše promocije,

- rizik od izbora neadekvatnih kanala prodaje i plasmana proizvoda i dr.

Rizici u primeni poslovne koncepcije su:

- rizik od pogrešne primene dobrih poslovnih strategija,

- rizik od pogrešnog operativnog menadžmenta,

- rizik od lošeg funkcionisanja kanala distribucije i dr.

Razvoj novog proizvoda izuzetno je rizičan i postoje tri vrste rizika i to:

- tehnološki rizik,

- rizik performansi,

- ekonomski rizik. 


\section{Upravljanje rizicima}

„Upravljajte rizicima svog poslovanja, da oni ne bi upravljali vama!" (Avakumović \& Avakumović, 2007) Neke rizike poslovanja menadžeri mogu izbeći ali postoje rizici koji se ne mogu izbeći. Veoma je bitno poznavati moguće rizike koji mogu nastati u poslovanju PPS-a, posebno u smislu:

- karaktera, obima i izvesnosti poslovanja,

- signala koje predhodno odaju i manifestacija njihovog poslovanja,

- metoda njihovog identifikovanja, izbegavanja, otklanjanja i relativiziranja,

- posledice koje nastaju, ukoliko se određeni rizici ostvare,

- kreiranje i operacionalizacija postupaka i procedura za sanaciju ugroženog stanja, kada se rizična mogućnost dogodi kao $\mathrm{i}$

- definisanje i konstituisanje postupaka i procedura za izbegavanje ili otklanjanje ponovnog ispoljavanja događaja rizičnog karaktera.

U svakom poslovanju PPS-a postoji više nego dovoljno rizika. Njihovo blagovremeno prepoznavanje i posezanje za odgovarajućim protivmerama je veoma važan zadatak vlasnika PPS-a.

Upravljanje rizikom malog biznisa obuhvata dve faze upravljačkih zadataka, i to:

- identifikaciju i analizu rizika koji mogu da prouzrokuju štetu ili gubitak i

- odabiranje i primenu najboljeg načina za eleminisanje svakog od ispoljenih rizika.

\subsection{Identifikacija i analiza rizika}

Indetifikacija opasnosti kojima je poslovanje malog biznisa izloženo, prvi je veoma važan korak u upravljanju rizicima poslovanja PPS-a. Da bi se uspešno ostvarila identifikacija, analiza i procene mogućih rizika poslovanja PPS-a, neophodno je da menadžment PPS-a dobro bude informisan:

- karakteru, izvorima i manifestacijama ispoljavanja rizika i

- načinima za njihovo izbegavanje i/ili eleminisanje.

Štete koje mogu nastati ostvarivanjem određenih rizika, mogu se ispoljiti kroz:

- gubitak imovine,
- gubitak zbog snošenja odgovornosti,

- gubitak poslovog ugleda i osvojene ekonomske i društvene pozicije,

- gubitak važnih saradnika i druge gubitke.

I. Gubitak imovine u samostalnom biznisu najčešće je posledica jednog od sledećih uzroka:

a) fizičko oštećenje imovine, do koga može doći zbog mnogih opšte poznatih opasnosti: požara, oluje, poplave, vandalizma neodgovornih lica $i$ drugih razloga.

b) gubljenje mogućnosti upotrebe resursa za posao, čak i u onim slučajevima kada PPS nije pretrpelo nikakvu štetu. Navedeno može da se desi ukoliko nadležna inspekcija, odnosno neki nadležni državni organ, zatvori deo ili ceo PPS zato što je prekršila neke važeće propise.

c) kriminalne aktivnosti raznih vrsta izvesne su u svakom poslovanju PPS-a, posebno onom gde se angažuje novac i materiijalne vrednosti radi obavljanja opredeljenog posla. Raspoloživa imovina i karakter posla opredeljuju i karakter opasnosti koje iz ovog domena prete PPS-u.

Gubitak imovine do kog može doći ne ispoljava se samo u nedostatku materijalnih i novčanih resursa, već i u gubitku prihoda koji se ostvaruju na osnovu navedenih resursa. $U$ toku prekida rada, do kog dolazi u koliko se rizik ostvari, ne samo što prihodi bivaju redukovani ili potpuno zaustavljeni, nego se šteta povećava zato što mnogi troškovi i dalje traju, posebno troškovi fiksnog karaktera, kao što su: otplate kredita, bankarske kamate, porezi, bruto plate ključnim radnicima, amortizacija i komunalije. Prekid rada često izaziva i ekstra troškove.

Do problema i gubitka imovine može doći i u slučaju ako se šteta desi negde vani, kod nekog vama važnog komitenta: dobavljača, kupca, transportera, skladištara, bankara ili drugog.

II. Gubitak poslovnog ugleda i osvojene ekonomske i/ili društvene pozicije, može nastati po faznim osnovama. Za mnoge PPS-ove gubitak ugleda i pozicije može biti opasniji nego gubitak novca i materijalnih resursa.Posebno za one, koje upravo na osnovu ugleda i pozicije ostvaruju svoje poslovanje.

III. Gubitak zbog odgovornosti za nanetu štetu takođe nastaje po nekoiko osnova.

Ova odgovornost može da bude rezultat: 
- sudske odluke,

- zakonskih odredbi,

- kršenje odredbi ugovora.

a) Građansko pravna odgovornost se može utvrditi na osnovu sudske ili na drugi način poravnavanje sukobljenih strana. PPS se može smatrati odgovornim za povrede ili druge gubitke, koje bilo ko pretrpi kao posledicu nemarnosti ili greške. Mnogi od nastalih sporova rešavaju se preko suda, što za PPS često predstavlja dodatno fnansijsko opterećenje.

b) Odgovornost za štetu nanetu radnicima može snositi i po zakonskoj i po etičkoj osnovi. PPS u slučaju nesreće na radu dužan je da povredjenim radnicima nadoknadi izgubljeni dohodak, a takođe i troškove lečenja i druge obaveze iz invalidsko - penzijskog i zdravstvenog osiguranja.Ukoliko radnik premine zbog posledice nesreće na radu ili bolesti dobijene na radu, porodica tog radnika ima takođe pravo na utvrđeni iznos na račun PPS-a.

c) Odgovornost za nepoštovanje ugovora takođe se može ostvariti po raznim osnovama, zavisno od toga šta je ugovorom predviđeno i po kojoj osnovi ugovorene odredbe nisu ispoštovane.

Nepoštovanje određenih klauzula ugovora, kojim jedna strana nanosi štete drugoj, stvara se pravni osnov za naknadu štete, koja se može utvrditi $i$ nadoknaditi dogovoreno, a može i preko nadležnog suda.

\subsection{Izbor i primena metoda za eliminaciju rizika}

Rizike treba ne smao otkriti, već in treba otkloniti ili minimizirati. Svako treba da poznaje sve ozbiljne rizike koji mogu da ugroze njegovo poslovanje, a potom svakako sredstva i mere, sa kojima će izvesne rizike otkloniti ili eliminisati.

Sledeća tri koraka u postupku upravljanja rizikom, slična su onima sa kojima se ljudi susreću prilikom vođenja svojih ličnih finansija:

1. borba protiv izvesnog rizika i gubitka koje rizik izaziva ukoliko se ostvari.

2. izbor i implementacija odgovarajućih metoda i načina u cilju obezbeđenja sredstava ili drugih resursa, radi pokrića gubitka do kojih je došlo, jer se izvesni rizik nije mogao izbeći niti sprečiti.

3. borba protiv rizika i gubitka koji život i biznis nameću može se ostvariti na različite načine $u$ cilju obezbeđenja sredstava ili drugih resursa, radi pokrića gubitka do kojih je došlo jer se izvestan rizik nije mogao izbeći niti sprečiti.

Najbolji odnos prema poslovnim rizicima je taj da se merama strategijskog i operativnog menadžmenta, smanji verovatnoća njihovog dogadjanja.Drugi način odnosa prema rizicima jeste da se reducira potencijalni uticaj odredjenih negativnih dogadjanja, koji izazivaju rizik.

\section{Organizaciona šema menadžmenta rizikom}

Tokom proteklih godina menadžment rizikom veoma se razvio, te je stekao veoma bitan profil u najvećem broju velikih PPS-ova. Njegova uloga se značajno promenila od vremena kada je predstavljao puki kancelariski posao i prerastao je u organizovane stručne timove, koji su postal značajan resurs svakog ozbiljnog PPS-a. Nažalost u prošlosti, robustan process upravljanja rizikom nije uvek bio primeren. Brza izmena ovakvog programa u 80-tim i 90-tim godinama prošlog veka značila je das u mnoge kompanije požurile da se ukrcaju na brze vozove, koji su jurili pored njih ne čekajući putnike koji kasne. Investitori su očekivali brzo vraćanje uloženih sredstava dok je takmičenje među poslovno proizvodnim sistemima bilo u tome ko će prvi izneti novi ili poboljšani proizvod na tržište - ili bar ako ovo nije slučaj ostaviti takav utisak. Kao posledica ove trke došlo je do lomova i skandala koji su odjekivali tokom prošle decenije a iza ovakvih događaja stajao je, zapravo nedostatak jasnog usmerenja ili etičkih vrednosti.

\subsection{Funkcija menadžmenta rizikom}

Uloga menadžera rizikom, njegova ovlašćenja, obaveze i dužnosti kao i zahtevi koji se pred njega postavljaju, uključujući i pristup obavljanju poslova kontrole. Skladno savremenim trendovima U PPS-u i upravljanju poslovanjem, prema kojim će težište u budućnosti biti na fleksibilnosti, decentralizaciji, informacijama i komunikaciji, demokratskom stilu vođenja, timskom radu bez naglašene hijerarhije, inovatnosti i znanju, te promenjenim zahtevima koji se u skladu sa tim pred menadžera rizika postavljaju. Međunarodni skup specijalista (GTF Gyidance Task Force), oblikovao je dve godine nakon intezivnog rada novu definiciju menadžera za 21 vek. Menadžer rizika je nezavisna i objektivna savetnička aktivnost, koja se rukovodi filozofijom dodatne vrednosti $s$ namerom poboljšanja 
poslovanja PPS-a, ona pomaže organizaciji $u$ ispunjavanju njenih ciljeva sistematičnim in a discipline utemenjenim pristupom procenjivanju delotvornosti upravljanja rizicima organizacije, kontrole i korporativnog upravljanja. $U$ tu definiciju implementirana su novija očekivanja od menadžera rizika kojima u budućnosti valja udovoljiti. (Petronijević, 2009)

Osnovni zadaci menadžera rizikom su (Petronijević, 2009):

- ispitivati i oceniti ispravnost, istinitost i primenu računovodstvenih, finasijskih i operativnih kontrola i unaprediti uz najniže troškove efikasnu kontrolu,

- utvrditi obim usklađenosti sa postavljenim politikama, planovima i postupcima,

- utvrditi visinu iskazane imovine i osiguranja od gubitka,
- utvrditi pouzdanost informacija koje menadžment koristi za izveštavanje,

- oceniti poslovne aktivnosti zaposlenih i menadžmenta.

U savremenim velikim i srednje velikim PPS-a usvaja se koncepcija, po kojoj je menadžer rizika podređen upravi ili posebnom odboru za rizik (Slika 1). Odbor za rizik predstavlja savetodavno telo nadzornog odbora, a obično se sastoji od više predsednika ili potpresednika drugih preduzeća. Za ostvarivanje ciljeva PPS-a i realizacije postavljenih planova značajno je znanje i stručnost osoblja, te odgovarajući sistemi nagrađivanja i motivacije. $U$ uslovima nezadovoljstva i ne uvažavanja osoblja od strane poslodavca povećava se rizik pogrešaka, nepravilnosti pa čak i prevara.

Slika 1. Menadžment rizika u organizacionoj šemi PPS-a

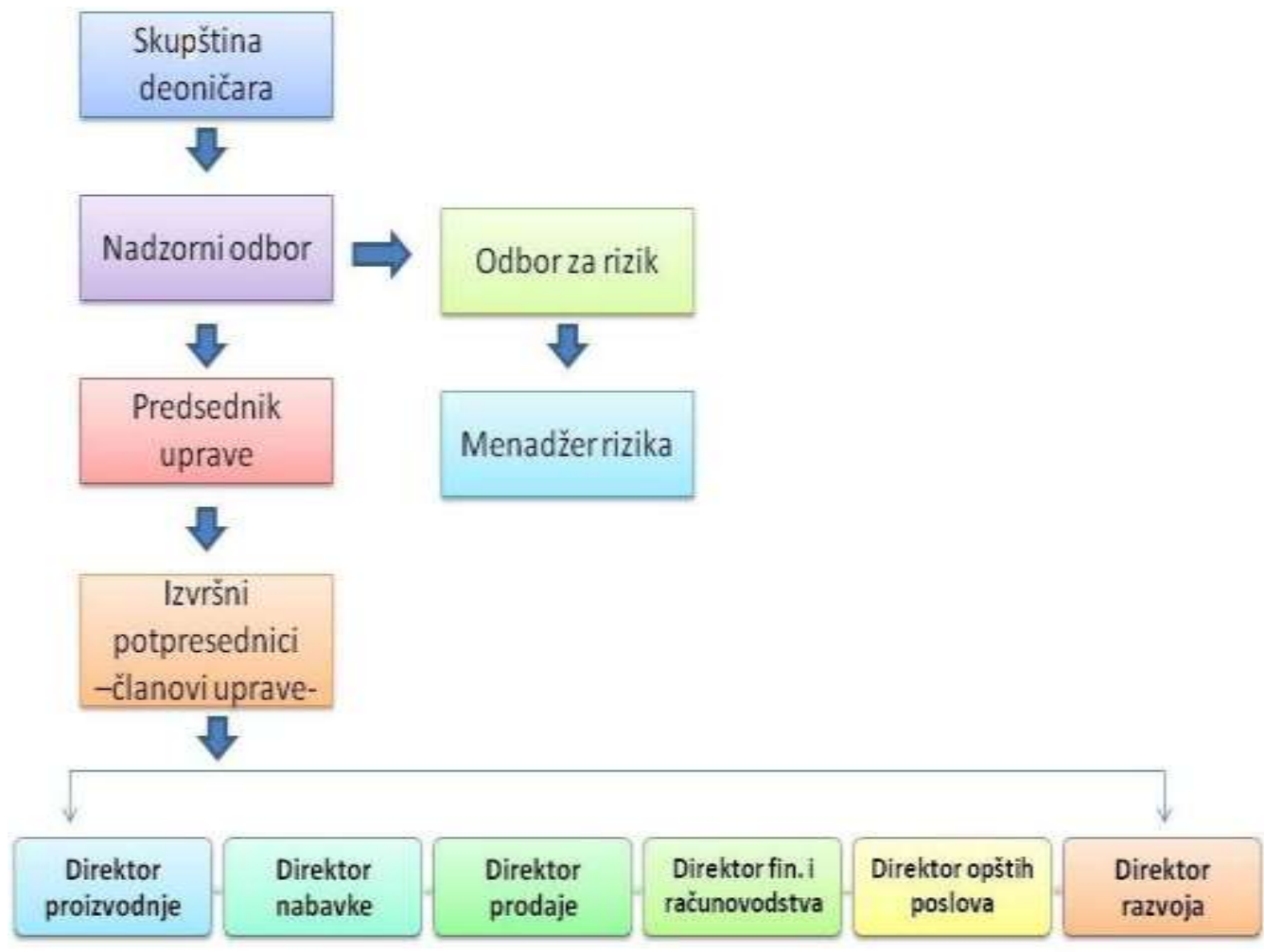

Bez obzira na organizacijski pristup - centralizovani ili decentralizovani treba poštovati pravilo po kojem su menadžeri rizika dužni izveštavati na organizacijskom nivou iznad nivoa koji ispituju. Primera radi, ne smatra se suprotnim načelu nezavisnosti ako menadžer rizika preporuči standard za kontrolni system ili ispita pojedine postupke pre nego se uvedu. Međutim, menadžer rizika ne bio bio nezavistan ako bi učestvovao kod oblikovanja i uvođenja kontrolnih postupaka u operativni system 
ili system elektronske obrade podataka. Menadžment rizika vrši oblik nadzora tj. kontrola iznad drugih kontrola, pa zbog toga menadžeri rizika ne smeju oblikovati ni uvoditi kontrole već je njihov osnovni zadatak nezavisno oceniti funkcionisanje već postojećih kontrola. Današnje osoblje unutrašnje kontrole rizika obično čine profesionalci različitog iskustva i profesionalne pozadine. Stvarni će stav osoblja zavisiti od činioca, kao što je vrsta poslovanja ili delatnost preduzeća, kao i pitanje oblika vlasništva PPS-a (javno ili privatno). Osoblje odeljenja koji se bave sprovođenjem menadžmenta rizikom u nekom većem preduzeću obično se raspoređuje na nekoliko nivoa, i to:

- pripravnik menadžer rizika,

- mlađi menadžer rizika ili asistent,

- menadžer rizika,

- rukovodilac odeljenja za kontrolu, upravljanje i merenje rizika.

\subsection{Proces kontrole rizika}

Mogući proces oblikovanja strategije interne kontrole prikazan je na slici 2. Taj process započinje analizom ciljeva i strategija PPS-a, sa obzirom na sasvim opravdan i logičan zahtev da strategija interne kontrole mora biti oblikovana tako da podupire ostvarivanje strategije PPS-a. sa obzirom na organizacijsko područje, strategija interne kontrole spade u funkcijske strategije koje se usredsređuju na oblikovanje i sprovođenje različitih aktivnosti, skladno dobijenim ovlašćenjima i Bez obzira na organizacijski pristup - centralizovani ili decentralizovani treba poštovati pravilo po kojem su menadžeri rizika dužni izveštavati na organizacijskom nivou iznad nivoa koji ispituju. Primera radi, ne smatra se suprotnim načelu nezavisnosti ako menadžer rizika preporuči standard za kontrolni system ili ispita pojedine postupke pre nego se uvedu. Međutim, menadžer rizika ne bio bio nezavistan ako bi učestvovao kod oblikovanja i uvođenja kontrolnih postupaka u operativni system ili system elektronske obrade podataka. Menadžment rizika vrši oblik nadzora tj. Kontrola iznad drugih kontrola, pa zbog toga menadžeri rizika ne smeju oblikovati ni uvoditi kontrole već je njihov osnovni zadatak nezavisno oceniti funkcionisanje već postojećih kontrola. Današnje osoblje unutrašnje kontrole rizika obično čine profesionalci različitog iskustva i profesionalne pozadine. Stvarni će stav osoblja zavisiti od činioca, kao što je vrsta poslovanja ili delatnost preduzeća, kao i pitanje oblika vlasništva PPS-a (javno ili privatno). Osoblje odeljenja koji se bave sprovođenjem menadžmenta rizikom u nekom većem preduzeću obično se raspoređuje na nekoliko nivoa, i to:

- Pripravnik menadžer rizika,

- Mlađi menadžer rizika ili asistent,

- Menadžer rizika,

- Rukovodilac odeljenja za kontrolu, upravljanje i merenje rizika.

\subsection{Proces kontrole rizika}

Mogući proces oblikovanja strategije interne kontrole prikazan je na slici 2. Taj process započinje analizom ciljeva i strategija PPS-a, sa obzirom na sasvim opravdan i logičan zahtev da strategija interne kontrole mora biti oblikovana tako da podupire ostvarivanje strategije PPS-a. sa obzirom na organizacijsko područje, strategija interne kontrole spade u funkcijske strategije koje se usredsređuju na oblikovanje i sprovođenje različitih aktivnosti, skladno dobijenim ovlašćenjima i resursima, kako bi se poboljšalo poslovanje preduzeća u celini.

Prikupljanjem relevantnih informacija utvrđuju se organizacijske jedinice koje će biti ispitane, te se identifikuju problemska područja i aktivnosti, unutar njih. Participacija menadžmenta $u$ tome je veoma značajna, jer ako strategija interne kontrole ne bude utemeljena na stvarnim potrebama PPS na svim nivoima, i u tom smislu izostaje saradnja sa menadžmentom, implementacija izabrane strategije interne kontrole biće znatno otežana. (Petronijević, 2009)

\subsection{Neke preporuke za preduzimanje mera smanjenja rizika}

Ako biznis koji obavljate može da stvori neke opasanosti preduzmite mere da rizike koji prete otklonite ili minimizirati, što se može postići na više različitih načina:

- Zdravlje i bezbednost tretirajte kao prioritet.

- Ukoliko primetite da se obavljaju poslovi koji nisu bezbedni odmah reagujte. Nemojte praviti izuzetke

- Uključite svoje ljude u sistem otklananja rizika, kako bi ste došli do što boljeg rešenja.

- Osmišljavajte nove i što bolje mere bezbednosti. 


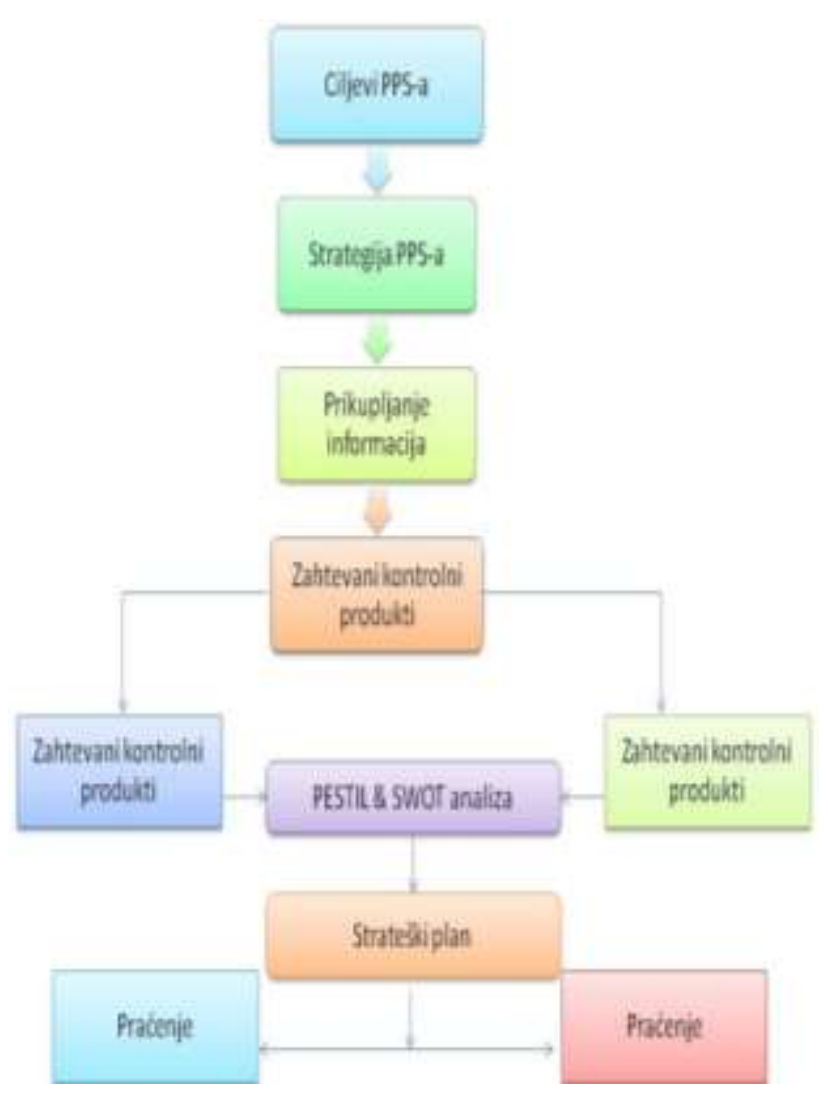

\section{Slika 2. Oblikovanje strategije interne} kontrole

- Uvek pođite od pretpostavke da će se ono što može da se dogodi i dogoditi.Budite aktivni i predvidite eventualne nesreće.

- Istaknite upozorenje i pravila vezana za zdravlje i bezbednost na vidnom mestu. Inovirajte in i redovno u njih unosite aktuelne informacije.

- Ako je tim kojim rukovodite veliki odredite koordinatora koji će voditi računa o tome da radnici i klijenti poštuju mere bezbednosti.

- Podržavajte i nagrađujte menadžere i radnike koji se ističu svojim radom i odnosom prema bezbedonosnim normativima i procedurama.

- Vodite računa o umoru koji je posledica prevelikih zahteva na poslu koje namećete radnicima.

- Ako je potrebno sprovedite i posebnu obuku kako da na bezbedan način koriste mašine $i$ opremu.

- Trudite se da radna sredina bude što bezbednija tako što ćete domaćinski brinuti o njoj.

- Analizirajte nezgode koje su se već desile. One su signali za opasnost.

- Vodite računa da vaši ljudi koriste odgovarajuću zaštitnu opremu.
- Vodite računa da medju vašim zaposlenima uvek postoje ljudi koji imaju položen ispit prve pomoći.

- Nove ljude nemojte uključivati u posao dok se ne upoznaju sa pravilima vezanim za zdravlje i bezbednost.

- Pažnja u nastupu bažično je sredstvo za smanjenje mnogih rizika.

- Ne ulazite u veće rizike, ako vam to ne donosi i veću zaradu

\section{ZAKLJUČAK}

Sistemi u okruženju (tehnički, biološki, ekološki, ekonomski, društvenih) su sve kompleksniji. Često prisutna protivurečnost njihovih ciljeva uslovljava neodređenost, a neretko i neizvesnost parametara ovih sistema. $U$ program planiranja rizika identifikuju se, analiziraju i tumače potencijalni rizični događaji i formiraju scenariji razvoja identifikovanih događanja. Kvalitet procesa izbora, realizacije i korekcije operativnih rešenja zavisi od umeća rukovodstva da raspoložive snage adekvatno iskoristi za eliminisanje uzoraka rizičnih događaja $\mathrm{i}$ njihovih posledica. Organizacioni mehanizmi u sistemima upravljanja rizikom moraju biti u stanju da prepoznaju nove problem, donose i realizuju nova rešenja, obezbede mogućnost maksimalne koncentracije resursa, objedine postojeće reserve i mobilišu snage da za najkraće vreme saniraju posledice rizičnog događaja. Tokom nekoliko poslednjih godina, važnost jakog korporativnog upravljanja u upravljanju rizikom se sve više propagira. Organizacije su pod pritiskom da identifikuju sve rizike vezane za njihovo poslovanje sa kojima se susreću, društveno, etičko, finasijsko, operativno okruženje, kao i životna sredina i oni moraju da objasne kako ove rizike svode na prihvatljiv nivo. $U$ međuvremenu, korišćenje okvira upravljanja rizikom u čitavom PPS-u se proširilo, jer PPS-ovi prepoznaju svoje prednosti nad manje koordiniranim pristupima upravljanja rizikom.

Kod procene značajnih poslova sa ozbiljnim rizikom treba da se konsultujete sa stručnjacima, ljudima koji su najbolje informisani.

Potrebno je da preduzetnici u malom biznisu budu dovoljno informisani i upućeni u materiju, odnosno u biznis kojim se bave, jer on sam mora odlučiti i doneti ispravnu odluku koja neće ugroziti njegov biznis i/ili će nastali rizik minimizirati. No važno je i znati, da bez rizika nema ni profita. 


\section{Citirani radovi}

Avakumović, Č., \& Avakumović, J. (2007). Menadžment. Novi Beograd: VTŠ.

Avakumović, J., \& Bojović, P. (2010). Savramani finansijski menadžment. Beograd: ICIM +. Jokić, D. (2007). Preduzetništvo. Užice: ICM.

Milosavljević, M. (2006). Strategijski menadžment. Beograd: Ekonomski fakultet.

Petronijević, M. (2009). Upravljanje rizikom. Novi Beograd: VTŠ.

Datum prve prijave:

Datum prihvatanja članka:
10.09.2012.

16.11.2012.

\section{Kako citirati ovaj rad?}

Style - APA Sixth Edition:

Avakumović, J., Avakumović, Č., \& Avakumović., J. (2013, 01 15). Upravljanje rizikom u poslovanju poslovnih proizvodnih sistema. (Z. Čekerevac, Ed.) FBIM Transactions, 1(1), 92-100. Retrieved from www.meste.org/fbim/FBIM 1 2013/ 10.pdf. doi: 10.12709/fbim.01.01.01.10

Style - Chicago Fifteenth Edition:

Avakumović, Jelena, Čedomir Avakumović, and Julija Avakumović. "Upravljanje rizikom u poslovanju poslovnih proizvodnih sistema." Edited by Zoran Čekerevac. FBIM Transactions (MESTE NVO) 1, no. 1 (01 2013): 92-100.

Style - GOST Name Sort:

Avakumović Jelena, Avakumović Čedomir and Avakumović. Julija Upravljanje rizikom u poslovanju poslovnih proizvodnih sistema [Journal] = Upravljanje rizikom u poslovanju PPS-a // FBIM Transactions / ed. Čekerevac Zoran. - Beograd : MESTE NVO, 01 15, 2013. - 1 : Vol. 1. - pp. 92-100.

Style - Harvard Anglia:

Avakumović, J., Avakumović, Č. \& Avakumović., J., 2013. Upravljanje rizikom u poslovanju poslovnih proizvodnih sistema. FBIM Transactions, 15 01, 1(1), pp. 92-100.

Style - ISO 690 Numerical Reference:

Upravljanje rizikom u poslovanju poslovnih proizvodnih sistema. Avakumović, Jelena, Avakumović, Čedomir and Avakumović., Julija. [ed.] Zoran Čekerevac. 1, Beograd : MESTE NVO, 01 15, 2013, FBIM Transactions, Vol. 1, pp. 92-100. 